\author{
Maciej J. Nowak ${ }^{1}$ \\ Roman M. Lozynskyy ${ }^{2}$ \\ Viktoriya Pantyley ${ }^{3}$
}

\title{
Local spatial policy in Ukraine and Poland
}

\begin{abstract}
The article aims to compare the local tools of Ukrainian and Polish spatial policy. It includes legal solutions (with a particular emphasis on the basics of development restrictions) and problems related to their application diagnosed in the literature on the subject. Based on the analysis of the spatial management systems of both countries, the similarities and differences were determined, referring them to the international discussion and suggesting directions for further research (on the spatial management systems of Central and Eastern European countries). Ukraine and Poland were selected for analysis in terms of similarities (partially similar historical conditions, location) and differences (status of a European Union Member State, spatial planning traditions).
\end{abstract}

Keywords: spatial management systems, local spatial development plans, comparisons JEL Classification Codes: R50, K49

1 West Pomeranian University of Technology, Szczecin, Poland, e-mail: macnowak@zut.edu.pl, https://orcid.org/0000-0001-8149-8995

2 Ivan Franko National University of Lviv, Ukraine, e-mail: roman.lozynskyy@lnu.edu.ua, https:// orcid.org/0000-0001-5435-7636

3 Maria Curie-Skłodowska University, Lublin, Poland, e-mail: wiktoria.pantylej@poczta.umcs.lublin. pl, https://orcid.org/0000-0002-7340-292X 


\section{Lokalna polityka przestrzenna na Ukrainie i w Polsce}

\section{Streszczenie}

Artykuł ma na celu porównanie lokalnych narzędzi ukraińskiej i polskiej polityki przestrzennej. Obejmuje rozwiązania prawne (ze szczególnym uwzględnieniem podstaw ograniczeń rozwojowych) oraz problemy związane $\mathrm{z}$ ich stosowaniem zdiagnozowane w literaturze przedmiotu. Na podstawie analizy systemów zagospodarowania przestrzennego obu krajów określono podobieństwa i różnice, odnosząc je do dyskusji międzynarodowej i sugerując kierunki dalszych badań (o systemach zagospodarowania przestrzennego krajów Europy Środkowo-Wschodniej). Do analizy wybrano Ukrainę i Polskę pod względem podobieństw (częściowo podobne uwarunkowania historyczne, położenie) i różnic (status członka Unii Europejskiej, tradycje planowania przestrzennego).

Słowa kluczowe: systemy zagospodarowania przestrzennego, miejscowe plany zagospodarowania przestrzennego, porównania

Kody klasyfikacji JEL: R50, K49

Issues about local spatial management systems in different countries are the subject of assessments and comparisons in the literature on the subject. The scope of the comparisons varies, and it is adapted to numerous national conditions (not only legal). The literature indicates that even the possible similarity of individual tools and legal regulations does not provide easy grounds for unambiguous analogies (Reimer et al., 2014: 7-24; Nadin, Stead, 2008: 35-47; Nadin, 2012: 1-5; Reimer, Blotevogel, 2012: 170-176). It also applies to the way spatial management systems are classified. Systems have been subjected to various classifications by, among others, Newman and Thornley (1996: 28-41), Larsson (2006: 21-49). The criteria considered include, i.a., linking the possibilities of development with real possibilities (including technical infrastructure), a certain discretion of local authorities in terms of shaping space, and the degree of connection between planning processes and legal regulations. A separate issue is also the definition of problems/challenges of national spatial management systems. For example, the following issues can be distinguished:

- The optimal scope of ownership rights restrictions in spatial planning (Alterman, 2010: 1-75).

- Europeanization of spatial policy (Davoudi, 2016: 31-38; Cotella, 2018:271-273).

- Informal institutions in the spatial policy.

- How to combine local planning with development policy.

- Flexibility in planning (Gielen, Tasan-Kok, 2010: 1097-1131). 
The article aims to compare the local tools of Ukrainian and Polish spatial policy. It includes legal solutions (with a particular emphasis on the basics of development restrictions) and problems related to their application diagnosed in the literature on the subject. Ukraine and Poland were selected for analysis in terms of similarities (partially similar historical conditions, location) and differences (status of a European Union Member State, spatial planning traditions). The article is part of the research field about comparing spatial management systems of different countries (Nowak, Gagakuma, Blaszke, 2020: 59-77).

\section{The spatial management system in Ukraine: basic characteristics}

After independence, Ukraine took over the Soviet spatial planning system, reflected in the existing terminology (Garat, 2019:2-3). The term "spatial planning" is not given in Ukrainian legislation. Still, the terms "city-forming" and "city-forming planning" are used, which refers to all types of areas - cities and larger regions and rural areas. Documentation in the field of spatial planning is called "city-forming documentation" (Jaroševska, 2015: 116-117). Modern terms (spatial development, spatial planning) have been actively introduced into practice only recently. City-forming activity is closely related to construction and land development, but the level of their unification is insufficient.

The Ministry for Communities and Territories Development of Ukraine is responsible for the spatial planning system in Ukraine. Legislation in spatial planning activities covers about 100 legal acts, including normative ones. The most important is the Legal Act on regulation of city-forming activity, approved in 2011 (Law of Ukraine, 2011). So far, no separate legal act has been adopted in Ukraine on spatial planning directly. The above-mentioned legal document plays a fundamental role in the field of spatial planning.

According to the spatial planning system, Ukraine officially distinguishes three levels of planning: national (state), regional ${ }^{4}$ and local. However, some authors also distinguish a sub-regional level. At the national level, the legal act on the General Scheme of Planning the Territory of Ukraine (Law of Ukraine, 2002), adopted in 2002, is in force. This document specifies the status for 2002 and the basic directions for the Ukrainian area and the General Scheme implementation stages.

\footnotetext{
4 Equivalent to the poviat level in Poland.
} 
Among the spatial policy instruments, the dominant ones relate to the city-forming activity (DBN B1.1-13:2021). In particular, at the local level, these direct instruments of spatial policy are to be used: general plans of urban and rural centers, area zoning plans, detailed area plans. The instruments of Ukrainian spatial policy have a decisive influence on the ongoing reform of the administrative and territorial system in the country. In 2020, a new administrative-territorial system in the country was approved, according to which the smallest administrative unit in the country is the so-called interconnected territorial communities. In June 2020, a legal act was adopted in Ukraine, introducing new types of documentation in the field of spatial planning: Comprehensive spatial development plan for the area of connected territorial communities and Concept for the integral development of areas of joined territorial communities. The first of the documents mentioned above is both a city-forming document and a document with questions regarding land development at the local level. However, these documents will not come into force in Ukraine until the summer of 2021 (Law of Ukraine, 2020).

In the current system, the basic tool used at the local level is the General Plan of a settlement unit. This document justifies a long-term planning and development strategy for a settlement. The zoning plan of the areas is developed based on the general plan of the settlement point to indicate the conditions and limitations of the use of the area for city-forming purposes within the indicated zones (DBN B.1.1-22: 2017). ${ }^{5}$ The detailed plan explains the settlement unit General Plan issues, ${ }^{6}$ which determines the planned organization and functional connections, spatial composition, and development parameters for the micro-region or other parts of the settlement area (DBN B1.1-15: 2012). For settlement units with a population of up to 50 thousand people, General plans may be combined with detailed plans for the entire territory of such settlement units (DBN B1.1-14: 2021).

The issues of restrictions and prohibitions regarding land development are included in the so-called City-forming conditions and constraints on the development of a plot of land (in Ukrainian: земельна ділянка - a land plot; geodetic, cadastral). A document contains a complex of planning and architectural requirements for designing in construction. At the local level, it is prepared considering the data of land cadasters and is to pass through the strategic ecological assessment approved by Ukrainian legislation. Development programs for regions and settlement units, economic, social, and cultural development programs should follow the city-forming documentation of the appropriate administrative and territorial level.

\footnotetext{
5 Equivalent to the Local spatial development plan.

6 Equivalent to the Study of the conditions and directions of spatial development in a commune in Poland.
} 
The central government may restrict or prohibit the activities of local authorities in the field of spatial planning if they do not comply with the active Ukrainian legislation. Responsibility for violations is often limited to fines, the size of which depends on the so-called Classes of consequences (responsibilities) for buildings.

\section{Key problems in the Ukrainian spatial development system}

According to the researchers, the biggest problem in Ukraine is the lack of order and inconsistency in the legal provisions about spatial planning. Its solution could be facilitated by adopting a separate Law of Ukraine on spatial planning, reflecting the contemporary world and European approaches in this field and appropriate terminology. A few years ago, a draft of such an act was prepared in cooperation with German partners (Brenner, 2017), but with the change of the central government, the prospects for its consideration are unknown. Some experts, more conservative, argue that instead of such an act, it is necessary to first agree on pre-existing documents and create the so-called "city-forming code" (Concepts, 2019: 76-89).

It is also considered important to develop a concept for the spatial development of Ukraine with clearly defined priorities, competencies, and planning tools at each hierarchical level. An important problem that needs to be addressed when updating the legislation is the existing official division of the spatial planning system in Ukraine into urban planning activities and spatial management activities by creating integrated spatial planning tools. Another unresolved problem in Ukraine is the poor functional link between spatial and strategic planning and socio-economic development programs (Danko et al., 2020; Dorosh, 2017: 29-31; Concepts, 2019: 41; Tkačuk, Vrublevskyi, 2009: 14; Ukraine, 2013: 43-44).

The General Planning Scheme of Ukraine's Territory also needs to be updated in the face of contemporary needs and social challenges. Most district planning schemes and master plans for urban and rural centers are outdated. Many problems arise from the administrative and territorial reform of Ukraine. Therefore, it is necessary to develop updated spatial planning documentation for new territorial units (Gerasymiuk, 2019: 151-154; Ščegliuk, 2019: 2-3; Ševčenko et al., 2020: 128-140).

The most serious problem at the local level is corruption in urban planning. The main cause of corruption, according to experts, is that the Ukrainian Act on regulating city-forming activities provides for the actual possibility of an investor interfering with the planning of housing estates and the possibility of pressuring local officials in creating city-forming projects (Concepts, 2019: 50). Article 10 of this Act, 
for developing detailed area plans, allows attracting funds from other sources permitted by law, i.e., most often the developer's funds. It allows the developer to stimulate decision-making processes financially. The other two important causes of corruption are complicated and non-transparent permit granting procedures and the developer's direct contact with the officials issuing the permits.

The developer often makes the following violations: exceeds the maximum permissible height of buildings, exceeds the maximum permissible percentage of buildings on a plot, exceeds the maximum permissible population density within residential buildings, deteriorates the arrangement of the area adjacent to the building. Such changes increase primarily the burden on the municipal infrastructure and worsen the living conditions of the inhabitants of the surrounding areas.

Corruption is related to poor quality planning documentation, financing of which is legally allowed by the developer or other (private) sources. It leads to ignoring the state and public interests and the imbalance in developing territories.

In Ukraine, there is also no effective system of penalties for violations in the field of spatial planning, including depriving designers of certificates for such violations. Fines are usually small and provide a little incentive not to break the law. There are many ways to lower the fine, and there are also patterns of underestimating the "consequences (liability)" of building unsuitable for legislation (Concepts, 2019: 15-26).

Public control over the field of spatial planning in Ukraine is ineffective. It applies in particular to the public hearings that take place before approving the detailed plans. Normative legal acts regulating the procedure of public hearings create barriers to their effective use in practice.

In many cities, because of spontaneous development, due to the investment attractiveness of historical centers, there is impunity and deliberate destruction and demolition of cultural heritage sites, and new buildings are erected in their place. Requirements and restrictions for construction in historic sites and protected areas are also ignored and violated. It is most often the case with privately owned monuments. Generally, in Ukraine, there is a weak link between the provisions on the protection of monuments and the provisions on spatial planning (Concepts, 2019: 47; Malchykova, 2014: 78).

In Ukraine, there is still no separate or similar specialty of Spatial planning in terms of the name or content in the higher education system. Specialists are trained by representatives of related specialties, such as: Architecture and urban construction, Geodesy and spatial management, and Geography (combines spatial planning with urban planning and regional development). There are still few specialists with appropriate, modern knowledge, qualifications, and competencies in spatial planning. 
A consequence of many problems in the field of spatial planning in Ukraine is the unauthorized construction of new properties (and reconstruction of the existing ones) with the violation or non-compliance with the permit-issuing procedures. This phenomenon is very difficult to stop (especially if such development is carried out on a plot belonging to the developer-owner, transferred to him/her for use, or even when carried out on the disputed territory). The emergence of unauthorized construction is mainly due to impunity, corruption, and a complex permit system. The phenomenon of unauthorized construction is also facilitated by the ineffectiveness of the architectural and construction supervision and control system, the complexity of the procedure for the demolition of unauthorized buildings, little penalty for violating legal requirements, construction norms, standards, and regulations.

In Ukraine, the instruments of environmental policy in the spatial planning system also do not function properly. For this purpose, two types of assessment are required: strategic environmental assessment and environmental impact assessment. However, often in developing documentation in spatial planning, such assessments are made only formally. The literature also draws attention to the lack of integration of the national ecological network concept with the practice of spatial planning and the lack of specific mechanisms in the country to ensure the achievement of sustainable development goals (Concepts, 2019: 43; Dudkina, 2014: 47; Ukraine, 2013: 35-41).

Due to all these problems, cities are seeing many buildings built in violation of building codes. All this distorts the urban space. Unsystematic spatial planning hinders the development of housing estates and creates an uncomfortable living environment.

\section{The spatial management system in Poland: basic characteristics}

The Polish spatial development system is one of those that (for example, in the group of European Union countries) attach particular importance to protecting the private property of real estate owners. It is a response to the times of communism (until 1989), in which the government administration carried out spatial planning. The changes after 1989 were aimed at correcting previous weaknesses. However, their authors did not always adequately diagnose the latest challenges and needs. But the term "spatial planning" is used by the legislator and applies to all (mutually diverse) types of areas.

In the Polish spatial development system, the key act from the perspective of the issues raised is the Act of March 27, 2003, on spatial planning and development. Besides that, it is possible to distinguish at least several dozen bills modifying/ 
supplementing (not always consistently) the basic spatial order included in the indicated Act. However, the problem is that currently there is no document that would define the spatial concept on a national scale. Until recently, it was the National Spatial Development Concept, but it was repealed. Its place is to be taken by the Concept of National Development.

In Poland, on a local scale, three key tools of spatial policy should be distinguished:

- Studies of conditions and directions of spatial development.

- Local spatial development plans.

- Decisions on building conditions and land development.

The studies do not constitute a universally binding legal act. They consist of a text and a graphic part. The text divides into two parts: analytical - informative, and directional. In the directional part, it is crucial to define the directions of changes in the spatial structure of the commune and land use and the directions and indicators for land development and use (including the designation of land for development). The study should define the concept of the spatial development of the commune. However, its guidelines do not always apply in practice (Nowak, Śleszyński, Ostrowska, 2020: 23-101).

The local spatial development plan should be the key tool of the spatial policy. It is a universally binding legal act with specific consequences for real estate owners or investors. It determines the purpose of the land and the detailed rules of its development (it also consists of a text and a graphic part). The new local plan must follow the content of the study. However, in Poland, over 60\% of the space remains without plans (Śleszyński, Kowalewski, Markowski, 2018: 50-99). The legislator did not introduce the obligation to adopt local plans. On the scale of the commune, it is possible to adopt plans for the entire area, any part chosen (by the commune authorities), or not to adopt such plans. Communes often fail to adopt plans fearing financial consequences (Kowalewski et al., 2013: 11-17).

In such a situation, the tool (if this term is adequate) of the spatial policy becomes an administrative decision issued by the executive body of the commune at the investor's request. When issuing, it is also verified theoretically whether the new development (to which the application relates) fits into the function of the surroundings. However, many such analyses are subjective and do not protect the spatial order effectively.

In the Polish spatial management system, the planning independence of a commune is a rule. However, it does not mean this principle is absolute. The interference of national and regional authorities is noticeable on many levels. On the one hand, they relate to sectoral issues, requiring, for example, the participation of individual authorities during planning procedures (e.g., environmental and nature protection, monuments, and cultural heritage protection). Thus, public administration bodies 
may block many works on a new study of the conditions and directions of spatial development, a local spatial development plan, and even a decision on building conditions and land development. Separately, as a limiting premise, it is possible to distinguish public purpose investments of supra-local importance and the so-called special acts, which create grounds for omitting the basic spatial order in connection with the necessity to implement selected categories of investments.

\section{Key problems in the Polish spatial management system}

The spatial management system in Poland has been diagnosed with numerous (mutually strongly related) problems (Nowak, 2020: 23-101). In the literature on the subject, the lack of sufficient protection of the values of areas related to spatial order is most strongly emphasized (Markowski, 2010: 12-101). Despite the establishment of spatial order in the Act on spatial planning and development (and even the principles of protection and shaping of spatial order as a mandatory element of the local plan), in practice, local spatial policy tools do not guarantee its protection (Izdebski, 2013: 55-71). The consequence is uncontrolled development (including suburbanization), which is noticeable in many parts of the country. It is related to the documented costs of spatial chaos, diagnosed in the settlement, environmental (Giedych, 2018: 77-89), real estate, and transport dimensions.

Therefore, spatial chaos is a key problem, but it can be treated because of other problems. These include:

- Institutional weaknesses.

- Problems in the interdisciplinary approach to individual spatial policy tools.

- Moderate level of social capital.

The problem of institutional weaknesses can be understood broadly. On the one hand, it concerns the lack of implementation in key postulates related to integrated development planning or flexibility in planning. But it is linked to specific deficiencies (e.g., the Concept of National Spatial Development). It should be emphasized, however, that there is institutional weakness of specific tools, consisting of:

- Negligible effectiveness of studies of the conditions and directions of spatial development (their translation into communal practice is often negligible).

- Limited role of local spatial development plans, both from the perspective of the area covered by them and insufficient protection of the spatial order (too many local plans allow for development to a great extent).

- The role of the decision on building conditions and land development, which is detrimental to the spatial development system. 
An overly broad understanding of property ownership rights is also a significant problem. It often results in excessive restrictions for communal spatial policies (also enforced at the stage of judicial decisions).

The tendencies mentioned above are deepened by the differentiation of expectations of various representatives of disciplines related to the spatial management system (town planners, geographers, lawyers, economists, environmental protection specialists, etc.), which, under the current formula of tools, are very difficult to reconcile consistently and unambiguously. It contributes to the deepening of spatial conflicts. While universities have faculties related to spatial management, the role of urban planners is still underestimated in the current system.

The above is reflected in the level of social capital in the context of the spatial development system's objectives. In communes, it is low, which often facilitates planning decisions that degrade space (as in Ukraine, attention is drawn to the negative role of developers in this context). It makes it difficult to understand space as public good.

\section{Ukrainian and Polish spatial management system: comparison}

Ukraine and Poland, during the liquidation of communism in Eastern Europe and the collapse of the USSR, faced different starting conditions. In Ukraine, which was part of the USSR, the level of communization and the related centralization of all spheres of social life was much higher than in Poland, which negatively impacted the Ukrainian spatial planning system's formation. Besides, until 1991, Ukraine was not an independent state, and in the 1990s, the main task was to expand the institution of statehood.

Much later than Poland, Ukraine implemented the reform of the administrative-territorial system and has not completed the decentralization of power related to the reform yet. The factor mentioned above also significantly influenced the development of spatial planning instruments in the country. In Ukraine, this reform is currently associated with a significant improvement in the spatial planning situation. However, the experience of Poland shows that the administrative and territorial reform and decentralization of power will not solve most problems of spatial planning, especially those related to the pressure from developers.

As of 2020, based on the democracy index (EIU, 2020), Ukraine is still a country with a transit regime, while Poland has long been in the group of countries with "imperfect democracy." The level of civil society development in Ukraine is lower than in Poland, which largely determines spatial planning instruments. 
Based on the presented analyses, it is possible to identify both the similarities and differences in the spatial management systems of Ukraine and Poland. The similarities (varying in their scope) include:

- Institutional problems - in Ukraine, they consist in the lack of the main law dealing directly and comprehensively with matters related to spatial planning and development. In Poland, they consist in broadly understood inconsistencies and inconsistencies in statutory solutions. In both cases, partially and chaotically matters related to spatial planning are reflected in other acts.

- Problems with expressing the concept of spatial development at the national level (which also translates into local spatial planning).

- Incomplete role of spatial development plans, related to the possibility of their (frequent) replacement by administrative decisions, based on which specific buildings can be forced.

- Accusations regarding the quality of planning works and problems related to their inclusion in the educational sphere.

- Weaknesses in public consultations.

- The inability to combine different perspectives and disciplines in the context of spatial planning (an example of which in both countries are problems with ensuring the protection of cultural heritage by spatial policy tools).

- Strong investment pressure (from developers), often blocking the protection of spatial order.

Table 1. Directions of common problem solutions in spatial policy systems of Ukraine and Poland

\begin{tabular}{|l|l|}
\hline \multicolumn{1}{|c|}{ Problem } & \multicolumn{1}{|c|}{ Solution } \\
\hline Institutional problems & $\begin{array}{l}\text { To make the necessary legal adjustments, to sensitize public authorities at } \\
\text { various levels to spatial planning problems. }\end{array}$ \\
\hline Role of spatial development plans & $\begin{array}{l}\text { Spatial plans must be - not just declaratively but realistically - a key tool } \\
\text { for spatial planning. This requires limiting the role of their substitutes } \\
\text { (e.g., administrative decisions). }\end{array}$ \\
\hline Quality of planning works & $\begin{array}{l}\text { Developing a stronger basis in science for local planning work. Nurturing the } \\
\text { relationship between scientific recommendations and planning practice. }\end{array}$ \\
\hline Public consultations & $\begin{array}{l}\text { Developing public consultations in both countries (independent of } \\
\text { adjustments to spatial planning systems). }\end{array}$ \\
\hline Investment pressure & $\begin{array}{l}\text { Creating a clear framework for investors that they cannot exceed. This will be } \\
\text { possible once the institutional role of public authorities is enhanced. }\end{array}$ \\
\hline
\end{tabular}

Source: own elaboration.

Table 1 provides directions for addressing the most relevant issues. The authors once again stress the specificity of each national spatial planning system. Nevertheless, 
common directions can be identified. In both cases, legal changes alone will not be sufficient. It is necessary to take care of both the appropriate approach of public authorities, planning education (combined with the scientific sphere), as well as linking the spatial planning system with other changes (e.g., in terms of public participation). Individual problems should not only be considered holistically but also individually. Each of them requires a slightly different approach.

The differences come down mainly to the severity of specific problems. Deficiencies in spatial planning at the national level result in deficiencies in the legal orders of numerous solutions discussed in the international literature (for example, regarding planning flexibility or extensive Value Capturing). In both cases, the protection of the rights of property owners (often manifested in the freedom of construction) should be considered too broad. In both cases (at least in the experience so far), there are no broader attempts to integrate development policies (in Poland, some limited changes, the effectiveness of which is currently difficult to assess, took place in the second half of 2020). There is also no strong (also in Poland - a Member State of the European Union) translation of European documents into local spatial policies.

The similarity of the indicated problems (as underlined, in different intensities) leads to the conclusion about common tendencies in Central and Eastern European countries. These tendencies have been signaled regarding certain issues and factors (Altrock, Guntner, Huning, Peters, 2016: 1-18; Maier, 2014: 215-234), but the dimension related to legal restrictions should be emphasized. Restrictions determined by bad, inconsistent law, combined with far-reaching forcing the role of investors in the spatial development system, result in negative effects on spatial chaos.

There are many similarities in the spatial management systems of both countries. Their joint isolation and compilation should cause wider conclusions and inspiration for further research. In terms of development directions, it can be assumed that there is a problem with planning culture in the countries of Central and Eastern Europe and with an institutional approach to spatial planning. It includes different scales: national (missing documents) and local (unclear regulations that can be easily circumvented). In many respects, there are no solutions known from Western Europe. The further direction of analyses and research should cause a wider diagnosis of other Central and Eastern European countries and develop common (not necessarily duplicating other solutions) recommendations. It is not only about defining the goal (because spatial management systems contain them) but indicating how these goals should be achieved. Undoubtedly, a serious contribution to such a definition 
should be a broader adjustment of spatial planning to social and economic planning and paying attention to situations in which legal regulations turn out to be ineffective. It also requires a broader definition of the needs related to various sectors of spatial planning (e.g., protection of monuments and cultural heritage) and the broadest possible connection and coherence of these perspectives.

There is no doubt that care for space and active use of spatial policy tools are important from the national perspective. Among other things, they make it possible to direct socio-economic development. When spatial policy tools fail to play their role, economic, social, and environmental problems arise (generated, inter alia, by spatial chaos). It is very difficult to make detailed analogies between the spatial planning systems of different countries, especially in the sphere of recommendations. Among other things, it must be remembered that legal changes will not be sufficient if they are not combined with broader attention to planning practice and planning culture. However, it can be pointed out that since Ukraine and Poland have institutional problems and problems of spatial chaos, they can be placed in one group in the classification of European systems (despite significant differences). They are neither flexible development-based systems (with well-developed public consultations) nor systems strongly based on spatial plans. What Ukraine and Poland have in common is that the declarations contained in the legislation are implemented to a moderate extent. On the one hand, it is possible to recommend changes to individual, most harmful regulations. In the Polish case, this could consist in modifying the form of the decision on development conditions, and in the Ukrainian case, in stopping unauthorized construction. Only such minor changes will create the basis for a well-thought-out reform. The reform may be based, inter alia, on the demands contained in the Territorial Agenda 2030 of the European Union, which encourage particular care for the environment, cultural heritage, and orderly development. In addition, the concept of a right to the city, discussed in the literature, is worth adopting at the scale of each national order (but also independently, at lower levels). This concept sensitizes public authorities precisely to the aspects to be taken into account in spatial planning adjustments. 


\section{References}

Alterman, R. (2010). Takings International: A Cross-National. In: Takings International: A Comparative Perspective on Land Use Regulations and Compensation Rights, R. Alterman, (Ed.). Chicago: American Bar Association: 1-75.

Altrock, U., Güntner, S., Huning, S., Peters, D. (2016). Spatial planning and urban development in the New EU Member States - Between Adjustment and Reinvention. In: Spatial Planning and Urban Development in the New EU Member States, U. Altrock, S. Güntner, S. Huning, D. Peters (Eds.). London: Routledge: 1-18. DOI: 10.4324/9781315242675

Brenner, Ya. (2017). Proekt zakonu pro prostorove planuvannja v Ukrajini [Project of the Law About spatial planning in Ukraine]. Sylni mista. Sylna Ukrajina. Bila knyga: Propozyciji ščodo administratyvno-pravovogo reformuvannja sfery mis'kogo rozvytku v Ukrajini (Dodatok 1). Kyjiv: GIZ.

Cotella, G. (2014). Spatial planning in Poland between European influence and dominant market forces. In: Spatial planning systems and practices in Europe. A comparative perspective on continuity and changes, M. Reimer, P. Getimis, H. Blotevogel (Eds.). New York, NY: Routledge: 271-273. DOI: 10.4324/9781315852577.

Danko, Yu. I., Medvid, Yu. V., Koblianska, I.I. (2020). Territorial Government Reform In Ukraine: Problem Aspects of Strategic Management. International Journal of Scientific \& Technology Research, 9(1): 1376-1382.

Daunora, Z.J., Juskevicius, P. (2016). Regional Planning in Lithuania - Experiences and Challenges In: Spatial planning and urban development in the new EU members states, U. Altrock, S. Güntner, S. Huning, D. Peters (Eds.). London: Routledge: 77-94. DOI: 10.4324/9781315242675

Davoudi, S. (2016). EU Enlargement and the Challenges for Spatial Planning Systems in the New Member States. In: Spatial planning and urban development in the new EU members states, U. Altrock, S. Günter, S. Huning, D. Peters (Eds.). London: Routledge: 31-38. DOI: $10.4324 / 9781315242675$

DBN B1.1-13:2012 "Sklad ta zmist mistobudivnoji dokumentacji na deržavnomu ta regionalnomu rivniach" Deržavni budivelni normy Ukrajiny. ['Composition and content of urban planning documentation on state and regional levels'. State building standards in Ukraine]. Retrieved from: https://dbn.co.ua/load/normativy/dbn/1-1-0-1025 (accessed: 20.02.2021).

DBN B1.1-14:2012 "Sklad ta zmist detalnogo planu terytoriji”. Deržavni budivelni normy Ukrajiny. ['Composition and content of detailed plan of the territory'. State building standards in Ukraine]. Retrieved from: https://www.minregion.gov.ua/wp-content/uploads/2018/02/ ZM_DBN_V1114.pdf (accessed: 20.02.2021).

DBN B1.1-15:2012 "Sklad ta zmist generalnogo planu naselenogo punktu”. Deržavni budivelni normy Ukrajiny. ['Composition and content of General scheme of settlement'. State building standards in Ukraine]. Retrieved from: https://anc-project.com/ua/dbn1/dbn-b.1.1-152012-sklad-ta-zmist-generalnogo-planu-naselennogo-punktu.html (accessed: 20.02.2021).

DBN B1.1-22:2017 “Sklad ta zmist planu zonuvanja terytoriji”. Deržavni budivelni normy Ukrajiny. ['Composition and content of zoning plan of the territory'. State building standards in Ukraine]. Retrieved from: http://dipromisto.gov.ua/files/NMD/DBN_Zoning_2017_1_ red.pdf (accessed: 20.02.2021). 
Doroš, A. (2017). Neobchidnist' zaprovadžennja prostorovogo planuvannja jak cilisnogo instrumentu upravlinnja zemelnyy resursamy v Ukrajini [Importance for implementation of spatial planning as integrated land management tool in Ukraine]. Zemleustrij, kadastr i monitoring zemel, 1: 28-34.

Dudkina, O. (2014). Planuvannja terytoriji: aspekty zabezpečennja zbalansovanogo rozvytku regioniv [Planning of territory: aspects of providing balanced development of regions]. Ukrajins'ka nauka: mynule, sučasne, majbutnie, 19(1): 42-50.

EIU (Economist Intelligence Unit) (2020). Democracy Index 2020: In sickness and in health? Retrieved from: https://www.eiu.com/n/campaigns/democracy-index-2020/ (accessed: 23.02.2021).

Garat, M. (2019). Genezys mistobudivnogo zakonodavstva Ukrajiny [Genesis of urban legislation in Ukraine]. Zovnišnja torgivlia: ekonomika, finansy, pravo, 5: 101-116. DOI: 10.31617/ zt.knute.2019(106) 09

Gerasymiuk, K.H. (2019) Stalyj rozvytok ob’jednanych terytorialnych gromad šliachom prostorovogo planuvannja [Sustainable development of joined territorial communities due to spatical planning. Pravo ta deržavne, 2(35): 150-155. DOI: 10.32840/pdu.2-1.24

Giedych, R. (2018). Ochrona przyrody w polityce przestrzennej miast. Studia KPZK PAN, t. CXC. Warszawa: Komitet Przestrzennego Zagospodarowania Kraju PAN.

Gielen, D.M., Tasan-Kok, T. (2010). Flexibility in planning and the consequences for publicvalue capturing in UK, Spain and the Netherlands, European Planning Studies, 18(7): 1097-1131. DOI: 10.1080/09654311003744191

Izdebski, H. (2013). Ideologia i zagospodarowanie przestrzeni. Warszawa: Wolters Kluwer Business: $55-71$.

Janin-Riviolin, U., Faludi, A. (2005). The hidden face of European spatial planning: Innovations in governance, European Planning Studies, 13(2): 195-215. DOI: 10.1080/0965431042000321785

Jaroševska, R.S. (2015) Teoretyko-pravovyj analiz poniattia mistobudivnoji dijalnosti [Theoreticallegal analysis of the notion of urban activity]. Pravo i suspilstvo, 5(3): 115-120.

Koncepciji publičnogo upravlinnja u sferi mistobudivnoji dijalnosti [Concepts of public management in the area of urban planning] (2019). Zbirnyk analityčnych materialiv. Kyjiv: projekt Integrovanyj rozvytok mist v Ukrajini. Retrieved from: http:/www.vin.gov.ua/images/ doc/vin/dep-dmba/news/Conc.pdf (accessed: 20.02.2021).

Kowalewski, A., Mordasewicz, J., Osiatyński, J., Regulski, J., Stępień, J., Śleszyński, P. (2013). Raport o ekonomicznych stratach i społecznych kosztach niekontrolowanej urbanizacji w Polsce. Warszawa: Fundacja Rozwoju Demokracji Lokalnej, IGiPZ PAN.

Larsson, G. (2006). Spatial Planning Systems in Western Europe: An Overview. Amsterdam: IOS Press.

Maier, K. (2014). Changing planning in the Czech Republic. In: Spatial planning systems and practices in Europe. A comparative perspective on continuity and changes, M. Reimer, P. Getimis, H. Blotevogel (Eds.). New York: Routledge: 215-234. DOI: 10.4324/9781315852577

Malchykova, D. (2014) The usage and planning of territory in Ukraine - aims, problems, needs. Stupskie Prace Geograficzne, 11: 77-88. 
Markowski, T. (2010). Planowanie przestrzenne i instrumenty jego realizacji w świetle teorii ułomnych rynków. In: Zarządzanie rozwojem przestrzennym miast, P. Lorens, J. MartyniukPęczek (Eds.). Gdańsk: Wydawnictwo Urbanista: 12-31.

Nadin, V. (2012). International comparative planning methodology: introduction to the theme issue, Planning Practice and Research, 27(1): 1-5. DOI: 10.1080/02697459.2012.669928

Nadin, V., Stead, D. (2008). European spatial planning systems, social, models and learning, disP - The Planning Review, 44(172): 35-47. DOI: 10.1080/02513625.2008.10557001

Newman, P., Thornley, A. (1996). Urban Planning in Europe. International Competition, National Systems and Planning Projects. London, New York, NY: Routledge: 28-41. DOI: $10.4324 / 9780203427941$

Nowak, M. (2020). Funkcje narzędzi polityki przestrzennej. Studia KPZK PAN, t. 5/197. Warszawa: Komitet Przestrzennego Zagospodarowania Kraju PAN.

Nowak, M., Gagakuma, D., Blaszke, M. (2020). Spatial Management Systems in Ghana and Poland - Comparison of Solutions and Selected Problems, World of Real Estate Journal. Świat Nieruchomości, 1(111): 59-77. DOI: 10.14659/WOREJ.2020.111.04

Nowak, M., Śleszyński, P., Ostrowska, A. (2020). Orzeczenia sądów administracyjnych w systemie gospodarki przestrzennej - perspektywa funkcjonalna i realizacyjna. Studium przypadku województwa mazowieckiego, Samorzą Terytorialny, 7-8: 109-128.

Reimer, M., Blotevogel, H. (2012). Comparing spatial practice in Europe: a plea for cultural sensitization, Planning Practice and Research, 27(1): 7-24. DOI: 10.1080/02697459.2012.659517

Reimer, M., Getimis, P., Blotevogel, H. (2014). Spatial planning systems and practices in Europe: a comparative perspective. In: Spatial planning systems and practices in Europe. A comparative perspective on continuity and changes, M. Reimer, P. Getimis, H. Blotevogel (Eds.). New York, NY: Routledge: 170-176. DOI: 10.4324/9781315852577

Ščegliuk, S.D. (2019). Prostorove planuvannja objednanych terytorialnych gromad $v$ umowach drugogo etapu decentralizacji: naukowo-analityčna zapyska [Spatial planning of joined territorial communities in the condition of the second stage of decentralization: scieintificanalytical note]. Lviv: DU „Instytut regionalnych doslidžen’ im. M.I. Dolišniogo NAN Ukrajiny. Retrieved from: http://ird.gov.ua/irdp/e20190302.pdf (accessed: 20.02.2021).

Ševčenko, O.V., Romanova, V.V., Žalilo Ya.A. et al. (Eds.) (2020), Decentralizacija iformuvannja polityky regionalnogo rozvytku $v$ Ukrajini. [Decentralisation and shaping of regional development policy in Ukraine]. Kyjiv: NISD.

Śleszyński, P., Kowalewski, A., Markowski, T. (2018). Studia nad chaosem przestrzennym, t. III, Synteza. Uwarunkowania, skutki i propozycje naprawy chaosu przestrzennego. Studia KPZK PAN, t. CLXXXII. Warszawa: Komitet Przestrzennego Zagospodarowania Kraju PAN.

Tkačuk, A., Vrublevskyi, O. (2009). Prostorove planuvannja dla ekonomičnogo zrostannja: analiz praktyky i zakonodavstva [Spatial planning for economic growth: analysis of practice and legislation]. Kyjiv: CuPol.

Ukraine: UNECE Country Profiles on Housing and Land Management (2013). EN/RU. Retrieved from: https://www.humanitarianresponse.info/en/operations/ukraine/document/ukraineunece-country-profiles-housing-and-land-management-2013-enru (accessed: 20.02.2021). 
Zakon Ukrajiny "Pro Generalnu schemu planuvannja terytoriji Ukrajiny" [Law of Ukraine "About General scheme of planning of the territory of Ukraine"] (2002). Vidomosci Verchovnoji Rady Ukrajiny (VVP), 30: 204. Retrieved from: https://zakon.rada.gov.ua/laws/show/305914\#Text (accessed: 20.02.2021).

Zakon Ukrajiny "Pro reguliuvannja mistobudivnoji dijalnosti" [Law of Ukraine "About regulation of urban planning activity"] (2011). Vidomosci Verchovnoji Rady Ukrajiny (VVP), 34: 343. Retrieved from: https://zakon.rada.gov.ua/laws/show/3038-17\#Text (accessed: 20.02.2021).

Zakon Ukrajiny "Pro vnesennja zmin do dejakych zakonodavčych aktiv Ukrajiny ščodo planuvannja vykorystannja zemel" [Law of Ukraine "About making changes in selected legislative acts on land use planning"] (2020). Vidomosci Verchovnoji Rady Ukrajiny (VVP), 46: 394. Retrieved from: https://zakon.rada.gov.ua/laws/show/711-20\#Text (accessed: 20.02.2021). 